\title{
Characterization of a Streptomyces-lividans- type site-specific DNA modification system in the avermectin-producer Streptomyces avermitilis permits investigation of two novel giant linear plasmids, pSA1 and pSA2
}

\author{
Meirwyn Evans, ${ }^{1}$ Frank S. Kaczmarek, ${ }^{2}$ Kim Stutzman-Engwall ${ }^{2}$ \\ and Paul Dyson ${ }^{1}$
}

Author for correspondence: Paul Dyson. Tel: +44 792 295667. Fax: +44 792295447.

\footnotetext{
1 Molecular Biology

Research Group, School of Biological Sciences, University College of Swansea, Singleton Park, Swansea SA2 8PP, UK

2 Bioprocess Research, Pfizer Central Research, Groton, CT 06340, USA
}

\begin{abstract}
The degradation of Streptomyces avermitilis DNA samples analysed by conventional pulsed-field gel electrophoresis was shown to be due to Trisdependent, double-strand cleavage. Using alternative electrophoretic conditions, separation of intact DNA molecioles was achieved, permitting the identification of two novel giant linear plasmids: the $100 \mathrm{~kb}$ pSA1 and $250 \mathrm{~kb}$ PSA2. Use of PSA2 DNA as a probe showed that PSA1 does not cross-hybridize, indicating that the plasmids are not closely related. The site-specificity of the DNA modifications, which render the DNA susceptible to Tris-dependent cleavage, was found to be essentially identical to that of similar modifications found in the DNA of S. lividans.
\end{abstract}

Keywords: Linear plasmids, DNA modification, Streptomyces avermitilis.

\section{INTRODUCTION}

Among prokaryotes, Streptomyces are unusual in that they often contain giant linear plasmids refractive to conventional separation techniques. With the application of pulsed-field gel electrophoresis (PFGE), it became possible to physically characterize examples of these plasmids, some of which had been surmised to exist due to their ability to promote conjugation and chromosomal recombination (Kinashi et al., 1987). The paradigm is the $350 \mathrm{~kb}$ linear plasmid, SCP1 of S. coelicolor A3(2), which, as well as encoding fertility functions, contains the genes for methylenomycin biosynthesis and resistance. Genetic evidence for this plasmid was reported by Vivian (1971), although physical isolation using PFGE was described only more recently (Kinashi \& Shimaji-Muruyama, 1991).

Another conjugative plasmid, SLP2 of $S$. lividans (Hopwood et al., 1983), initially proved impossible to isolate even by application of PFGE. S. lividans possesses a site-specific DNA modification system which renders its DNA susceptible to double-strand scission during electrophoresis in Tris buffers (Ray et al., 1992; Zhou et al., 1988). As a consequence, extensive degradation of the DNA occurs during PFGE, so that neither chromosomal nor plasmid DNA can be resolved as discrete molecules. To visualize SLP2, it was necessary first to transfer the plasmid either to heterologous hosts which do not modify DNA or to a non-modifying mutant, prior to preparing samples for PFGE (Chen et al., 1993). However, the $50 \mathrm{~kb}$ linear plasmid could also be resolved by PFGE of wildtype $S$. lividans DNA by changing the electrophoretic conditions; either by substituting HEPES for Tris in buffers used for sample preparation and electrophoresis, or by including a reducing agent in a Tris-based electrophoresis buffer (Evans \& Dyson, 1993). Thiourea, for example, can reduce the reactive oxidative Tris derivative, formed at the anode during electrophoresis, which causes double-strand cleavage of the DNA (Ray et al., 1992; T. Ray \& P. Dyson, unpublished).

S. avermitilis produces an important series of 16 -membered macrocyclic lactones known as avermectins which are potent antiparasitic compounds with broad-spectrum activity against nematode and arthropod parasites (Burg et al., 1979). A natural fertility system has been used to demonstrate linkage between avermectin biosynthetic genes, although it was not possible to associate chromosomal recombination with plasmid fertility functions as is the case for both SCP1 in S. coelicolor and SLP2 in S. lividans (Ikeda et al., 1987).

Attempts to physically characterize the genome of $S$. avermitilis by PFGE have been thwarted as the DNA is prone to degradation (Kieser et al., 1992). In this study we 
have demonstrated that this degradation is attributable to modification of the DNA, similar to that occurring in $S$. lividans, rendering it susceptible to Tris-dependent cleavage during electrophoresis. Hence, using non-degradative PFGE conditions already determined in our laboratory (Evans \& Dyson, 1993), we have now succeeded in identifying and investigating two giant linear plasmids present in $S$. avermitilis.

\section{METHODS}

Bacterial strains, plasmids and culture conditions. Streptomyces strains and plasmids are listed in Table 1. Cultures were grown on GHM agar (glucose, $4 \mathrm{~g} \mathrm{l}^{-1}$; yeast extract, $4 \mathrm{~g} \mathrm{l}^{-1}$; malt extract, $10 \mathrm{~g} \mathrm{l}^{-1}, \mathrm{CaCO}_{3}, 2 \mathrm{~g} \mathrm{l}^{-1}$; agar $15 \mathrm{~g} \mathrm{l}^{-1}, \mathrm{pH} \mathrm{7 \cdot 2)}$ and, for liquid cultivation, in tryptic soy medium (Dyson \& Schrempf, 1987). Plasmid-curing was achieved by nitrosoguanadine mutagenesis (Hopwood et al., 1985) using conditions permitting $10 \%$ survival.

Preparation of inserts and pulsed-field gel electrophoresis. To prepare gel inserts, mycelia were harvested by centrifugation from 3 or 4-d-old liquid cultures. The procedure subsequently followed was originally developed to prepare gel inserts of $S$. lividans DNA, and differs from standard protocols in that for all buffers Tris was replaced by HEPES (Evans \& Dyson, 1993). Standard methods were used to prepare inserts containing yeast [Saccharomyces cerevisiae K107 (Nasmyth, 1982)] chromosomes or bacteriophage lambda concatamers (Sambrook et al., 1989). PFGE was carried out using a Bio-Rad contour-clamped homogeneous electric field (CHEF-DRII) system. Pulse times were $60 \mathrm{~s}$ for $18 \mathrm{~h}$, followed by $90 \mathrm{~s}$ for $5 \mathrm{~h}$ at $150 \mathrm{~V}$, with a running temperature of $14^{\circ} \mathrm{C}$ for gels run in $0.5 \times \mathrm{TBE}$ (Sambrook et al., 1989). Alternatively, gels were prepared and run in $1 \times$ HEPES $(16 \mathrm{mM}$ HEPES $/ \mathrm{NaOH} \mathrm{pH} 7 \cdot 5,16 \mathrm{mM}$ sodium acetate, $0.8 \mathrm{mM}$ EDTA) using similar pulse times, unless otherwise stated, at $130 \mathrm{~V}$, again with a running temperature of $14^{\circ} \mathrm{C}$.

DNA manipulations. Streptomyces plasmid DNA isolation was

\section{Table 1. Streptomyces strains}

\begin{tabular}{|lll|}
\hline Strain & Plasmids & $\begin{array}{c}\text { Source (alternative } \\
\text { designation) }\end{array}$ \\
\hline S. avermitilis 12804 & pSA1, pSA2 & $\begin{array}{c}\text { NCIMB* } \\
\text { (ATCC 31267) }\end{array}$ \\
S. avermitilis 31272 & pSA1, pSA2 & ATCC \\
S. avermitilis 31272 sc2 & pSA1 & This studyt \\
S. coelicolor A3(2) & SCP1, SCP2 & $\begin{array}{l}\text { D. A. Hopwood, } \\
\text { John Innes }\end{array}$ \\
& & Institute, UK \\
S. lividans & DLP2, SLP3 & D. Hopwood, \\
& & John Innes \\
& & Institute, UK \\
& & (1326, 'strain 66') \\
\hline
\end{tabular}

* National Collections of Industrial and Marine Bacteria, Aberdeen, UK.

† A single colony isolated after nitrosoguanidine mutagenesis of strain 31272 . based on an alkaline lysis method (Hopwood et al., 1985). Restriction enzymes were purchased from Gibco-BRL, and digests performed as recommended by the manufacturer. DNA was isolated from gel slices by agarose digestion with GELase (Epicenter Technologies), and subsequent ethanol precipitation.

Transformation procedures. Plasmid DNA was introduced into $S$. avermitilis by polyethylene-glycol-mediated transformation of protoplasts which were subsequently regenerated on RM14 medium (MacNeil \& Klapko, 1987). Transformants were selected and subsequently maintained by growth on media containing $10 \mu \mathrm{g}$ thiostrepton $\mathrm{ml}^{-1}$. Preparation and transformation of $S$. lividans protoplasts were done as described by Hopwood et al. (1985), transformants being selected and maintained on media containing $25 \mu \mathrm{g}$ thiostrepton $\mathrm{ml}^{-1}$.

Southern hybridization. After electrophoretic separation in agarose, DNA was transferred to Hybond N nylon membrane (Amersham) using a vacuum blotting system (Pharmacia or Stratagene). Probes labelled with either $\left[\alpha^{32} \mathrm{P}\right] \mathrm{dCTP}$ or digoxigenin-11-dUTP were prepared by random priming using a kit from Boehringer Mannheim. Radiolabelled probes were hybridized to membranes in a solution of $5 \times$ SCP $(20 \times$ SCP: $2 \mathrm{M} \mathrm{NaCl}, 0.6 \mathrm{M} \mathrm{Na}_{2} \mathrm{HPO}_{4}, 0.2 \mathrm{M} \mathrm{Na}_{2}$ EDTA), $10 \%$ (w/v) dextran sulphate (Pharmacia), $1 \%(\mathrm{w} / \mathrm{v}) \quad N$-lauroylsarcosine (Sigma), and $1 \mathrm{mg}$ heparin (Sigma) $\mathrm{ml}^{-1}$ at $65^{\circ} \mathrm{C}$ and washed twice with $2 \times \mathrm{SCP}, 0.1 \% \mathrm{SDS}$ at $65^{\circ} \mathrm{C}$ and twice with $0.2 \times \mathrm{SCP}, 0.1 \% \mathrm{SDS}$ at $65^{\circ} \mathrm{C}$ prior to autoradiography. For digoxigenin-labelled probes, hybridization conditions and subsequent detection by colour reaction with 4-nitroblue tetrazolium chloride and 5-bromo-4-chloro-3-indolyl phosphate were according to the manufacturer's instructions (Boehringer Mannheim).

Tris-dependent site-specific DNA cleavage. Plasmid DNA, previously digested with restriction enzymes, was purified by phenol/chloroform extraction and ethanol precipitation. The DNA was redissolved in $10 \mu \mathrm{l}$ of water to give a concentration of $1 \mu \mathrm{g} \mathrm{ml}^{-1}$, and then divided equally between two tubes prior to induction of Tris-dependent strand cleavage. A $500 \mu \mathrm{l} \mathrm{vol}$. of non-activated $1 \times$ TAE buffer $(40 \mathrm{mM}$ Tris, $20 \mathrm{mM}$ sodium acetate, $0.8 \mathrm{mM}$ EDTA, $\mathrm{pH} 7.5$ adjusted with acetic acid), maintained at $37^{\circ} \mathrm{C}$, was added to one tube, and $500 \mu \mathrm{l}$ of activated buffer, again maintained at $37^{\circ} \mathrm{C}$ and sampled from $5 \mathrm{~mm}$ adjacent to the anode of a horizontal gel chamber after applying a constant voltage of $80 \mathrm{~V}$ for $10 \mathrm{~min}$ (Ray et al., 1992), was added to the second tube. Both tubes were incubated at $37^{\circ} \mathrm{C}$ for $2 \mathrm{~h}$ prior to terminating cleavage by addition of $50 \mu \mathrm{l}$ $3 \mathrm{M}$ sodium acetate, $\mathrm{pH} 5$, and $550 \mu \mathrm{l}$ propan-2-ol. The DNA was precipitated, pelleted and redissolved prior to gel loading. DNA fragments were fractionated on a $0.9 \%$ agarose gel run in $1 \times$ HEPES buffer, prior to Southern hybridization.

\section{RESULTS AND DISCUSSION}

\section{PFGE of S. avermitilis DNA permits identification of two linear plasmids}

DNA prepared from $S$. coelicolor A3(2) could be resolved by PFGE in $0.5 \times$ TBE to give the characteristic profile of presumed circular chromosomal DNA retained in the well, linear chromosomal DNA, estimated at $8 \mathrm{Mb}$ (Kieser et al., 1992) just entering the gel, and the $350 \mathrm{~kb}$ SCP1 clearly resolved from the chromosomal DNA (Fig. 1a). However, DNA prepared from either $S$. lividans or $S$. avermitilis appeared as degraded fragments of $100 \mathrm{~kb}$ or 
(a)

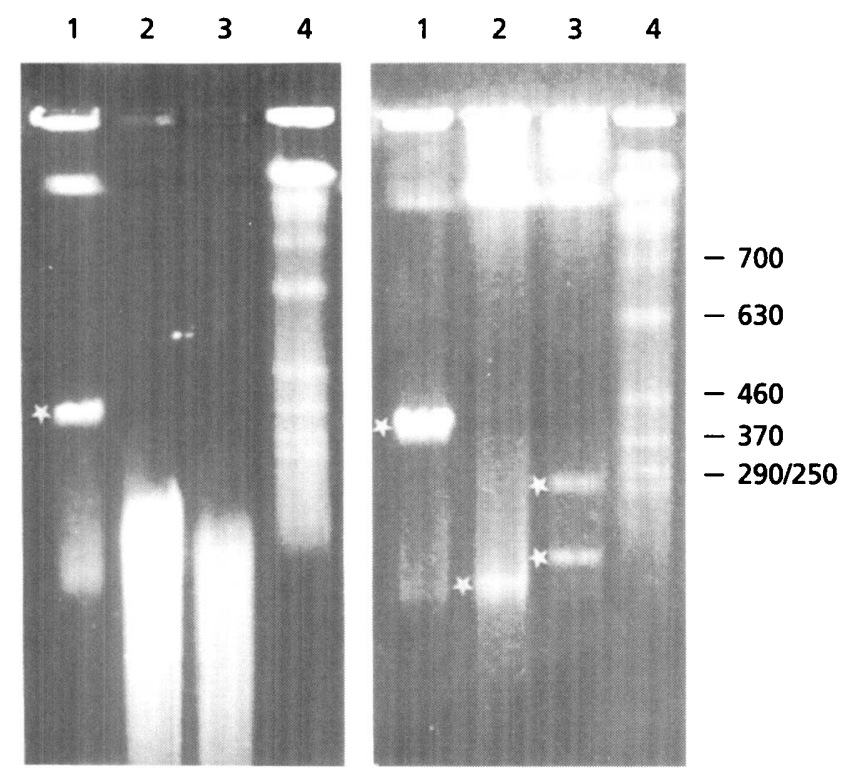

Fig. 1. Identification of Streptomyces linear plasmids by pulsedfield gel electrophoresis. Inserts prepared from $S$. coelicolor A3(2) (lane 1), S. lividans (lane 2), S. avermitilis 12804 (lane 3) and Saccharomyces cerevisiae $\mathrm{K} 107$ (lane 4) were electrophoresed in $0.5 \times \mathrm{TBE}$ (a) and $1 \times$ HEPES (b) buffers. Linear plasmids present in each Streptomyces species are starred (see text for details). The sizes (kb) of the resolved yeast chromosome markers are indicated.

less in gels run in $0.5 \times \mathrm{TBE}$, preventing identification of extrachromosomal elements.

In contrast, DNA from the same gel inserts prepared from all three species could be effectively resolved by PFGE in $1 \times$ HEPES buffer, revealing the $50 \mathrm{~kb}$ SLP2 linear plasmid in S. lividans, and two extrachromosomal elements estimated at $250 \mathrm{~kb}$ and $100 \mathrm{~kb}$ in S. avermitilis 12804 (Fig. 1b). To investigate the topology of the latter two elements, separate gels were run for different pulse times in $1 \times$ HEPES. During PFGE the extent of migration of circular molecules relative to linear molecules varies considerably according to pulse times (Matthew et al., 1988). Separate gels were run with pulse times of $25 \mathrm{~s}$ at $130 \mathrm{~V}$ for $18 \mathrm{~h}$ and $3 \mathrm{~min}$ at $130 \mathrm{~V}$ for $16 \mathrm{~h}$. Compared to the linear size markers used (yeast chromosomes and lambda concatamers), the relative migration of the two extrachromosomal elements of $S$. avermitilis did not change as a result of variation of pulse times. Therefore, it is concluded that the extrachromosomal elements of $S$. avermitilis are linear plasmids. Both linear plasmids were observed to be present in S. avermitilis 31272 .

In some species of Streptomyces it has been observed that certain plasmids can exist in more than one extrachromosomal form as a result of DNA rearrangements such as deletions and amplifications (Kieser et al., 1982; Kinashi, 1989). To investigate if the two $S$. avermitilis plasmids were related, their ability to cross-hybridize was tested. Preparative PFGE was used to isolate the $250 \mathrm{~kb}$ plasmid, which was subsequently purified and radiolabelled. The probe was hybridized to $S$. avermitilis DNA resolved by PFGE. It hybridized to the $250 \mathrm{~kb}$ plasmid but not to the smaller $100 \mathrm{~kb}$ plasmid, indicating that the two elements are unrelated. Hence, we conclude that $S$. avermitilis possesses two genetically dissimilar linear plasmids: one estimated at $100 \mathrm{~kb}$, here designated as pSA1, the other of $250 \mathrm{~kb}$, designated pSA2.

The pSA2 probe was also hybridized to DNA from $S$. avermitilis strain $31272 \mathrm{sc} 2$ that no longer contains the $250 \mathrm{~kb}$ plasmid as visualized by PFGE. There was no hybridization to either extrachromosomal or chromosomal DNA, indicating loss of pSA2 without concomitant chromosomal integration. As sporulation and avermectin production are both normal in this strain, it can be concluded that pSA2 does not encode functions which have significant effect on these processes.

To investigate other functions that might be present on the plasmids, we hybridized a DNA fragment previously shown to be involved in pigment production in $S$. avermitilis (Tibbetts et al., 1992). No hybridization was detected to either pSA1 or pSA2, although the probe did hybridize to chromosomal DNA. Hence, we conclude that pigment production is also not plasmid encoded. We are at present investigating other functions, including fertility, which could be encoded by one or other of the plasmids.

\section{Site-specific DNA modification in S. avermitilis}

The extensive degradation of $S$. avermitilis DNA in gels run in $0.5 \times \mathrm{TBE}$ contrasted with samples run either in $1 \times$ HEPES or in $0.5 \times$ TBE supplemented with $50 \mu \mathrm{M}$ thiourea (results not shown), indicating that fragmentation was not due to nuclease activity during insert preparation [as is evident for some other prokaryotes (Bancroft et al., 1989)], but to modifications in the DNA which are susceptible to Tris-dependent strand scission as is the case for $S$. lividans. Because S. lividans DNA modifications are highly site-specific (Dyson et al., 1986; Zhou et al., 1988), we were interested in assessing the specificity of the $S$. avermitilis modifications.

Plasmid pI J303 (Kieser et al., 1982) was introduced into $S$. avermitilis 12804 and $S$. lividans and then re-isolated from both species. The DNA was then digested with either $B a m \mathrm{HI}, B g / \mathrm{II}, B s c \mathrm{I}$, SacI, XhoI (enzymes with unique recognition sequences in the plasmid) or combinations of any two of these enzymes, prior to induction of Trisdependent site-specific cleavage. No fragmentation of pI J303 DNA isolated from either S. lividans or S. avermitilis was detected after incubation with non-activated Tris. In contrast, incubation with activated Tris resulted in fragmentation of the plasmid isolated from both species, giving, in both cases, similar fragment profiles (Fig. 2a). The sizes of fragments produced by Tris-dependent cleavage were calculated for each single and double restriction enzyme digest of $\mathrm{pIJ} 303$, and a map of the 14 predominant cleavage sites was assembled (Fig. 2b). Cleavage did not result in equal proportions of every fragment, and the relative yield of each product was 
(a)

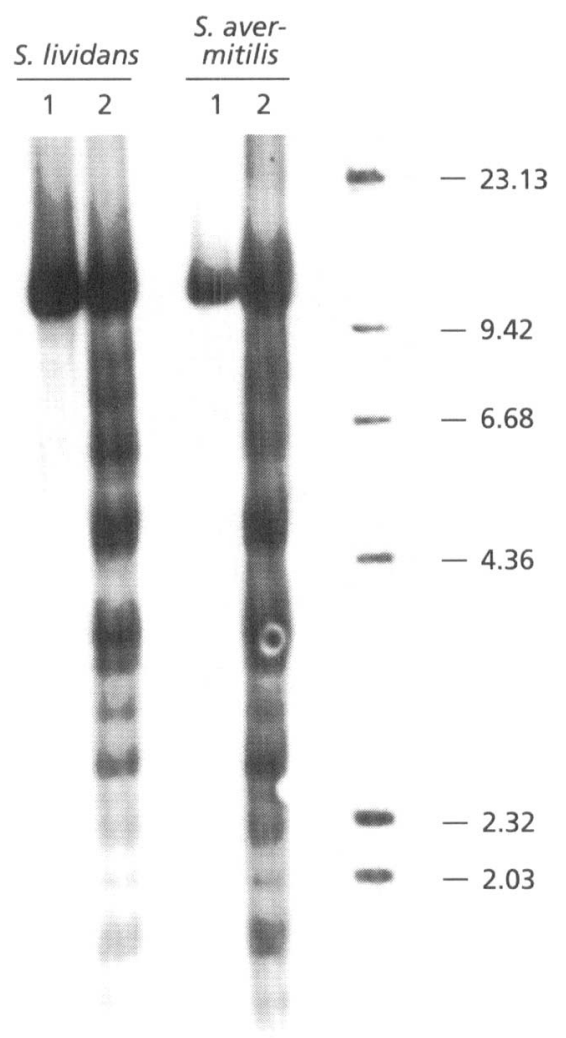

(b)

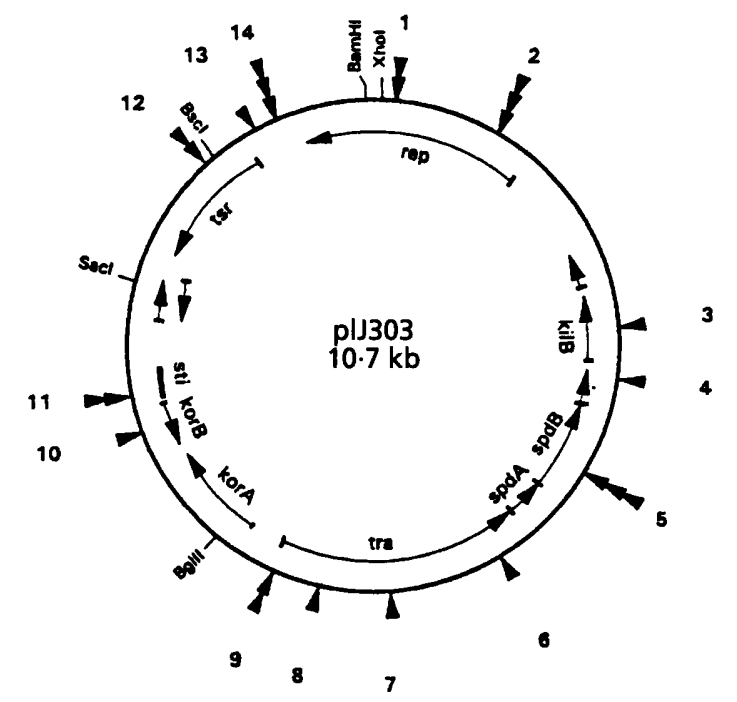

Fig. 2. Site-specific Tris-dependent cleavage of plJ303. (a) Plasmid DNA from S. lividans and S. avermitilis 12804 was linearized with BamHI and incubated with either non-activated (lanes 1) or activated (lanes 2) $1 \times$ TAE buffer and then run on an agarose gel in $1 \times$ HEPES buffer as described. The DNA was transferred to a nylon membrane and hybridized with a digoxigenin-labelled plJ303 probe. The sizes (kb) of photodigoxigenin-labelled bacteriophage lambda HindIII fragments (Boehringer Mannheim; lane 5) are indicated. (b) The locations of 14 Tris-dependent cleavage sites are indicated on the combined physical and genetic map of plJ303, itself compiled from the map of the progenitor plJ101 presented by Stein et al. (1989) and from data on the construction of plJ303 by Kieser et al. (1982). The qualitative frequency of cleavage (high, intermediate or low) at individual sites is represented by triple, double and single arrowheads, respectively.

reproducible and similar for DNA isolated from both species. This may represent differences in the frequency of in vivo modification at different sites in both species, or it could be a consequence of variable affinity of the oxidative Tris derivative for modifications at different sites. By measuring peak sizes from densitometry traces of individual lanes, we assigned each site to one of three categories, representing high, intermediate or low yield of cleavage product. The location of only one of these preferential cleavage sites [site 14 in Fig. $2 \mathrm{~b}$ has previously been mapped in the related plasmid pIJ101 (Zhou et al., 1988)]. Investigation to allow comparison of the precise DNA sequence of different modification sites is currently underway.

Our results indicate that $S$. avermitilis possesses an unusual system of DNA modification, previously identified only in S. lividans (Dyson et al., 1986; Zhou et al., 1988). DNA modification in the two species is comparable both in terms of the chemical nature of the modifications, which render them susceptible to Tris-dependent cleavage, and their site specificity. We are currently determining the nature and cause of this novel type of modification. In terms of DNA metabolism, these two species have previously been compared with regard to their ability to restrict methylated DNA (MacNeil, 1988). This study indicated that while $S$. lividans has a weak methyl-specific restriction system that can slightly reduce transformation frequencies with $N^{6}$-methyladenine-containing DNA, $S$. avermitilis possesses a methyl-specific restriction system that severely reduces transformation frequencies with DNA containing either 5-methylcytosine or $N^{6}$ methyladenine. Interestingly, it was observed that transformation of $S$. avermitilis with DNA from a methylasedeficient strain of Escherichia coli was less efficient than with DNA passaged through $S$. lividans. It is possible that the novel DNA modifications introduced by $S$. lividans could confer on the DNA a higher efficiency of transforming $S$. avermitilis, which, as we have demonstrated, shares a similar modification system. 
We are not aware of a systematic study into how widespread this type of DNA modification system is. That two well-studied but not obviously related species share the same phenomenon suggests it may occur in other actinomycetes. That $S$. coelicolor A3(2), a close relative of $S$. lividans, does not modify its DNA in this manner, suggests that not all species belonging to the same cluster group share the phenotype. The alternative conditions for PFGE we have used in this study should facilitate identification of other species which modify their DNA in a similar manner and enable physical analysis of their genomes.

\section{ACKNOWLEDGEMENTS}

We thank Trevor Ray for advice and assistance in preparation of the figures and Hamish McArthur for critical reading of the manuscript. This research was supported by grants to P.D. from the Society for General Microbiology and the Nuffield Foundation.

\section{REFERENCES}

Bancroft, I., Wolk, C. P. \& Oren, E. V. (1989). Physical and genetic maps of the genome of the heterocyst-forming cyanobacterium Anabaena sp. strain PCC 7120. J Bacteriol 171, 5940-5948.

Burg, R. W., Miller, B. M., Baker, E. E., Birnbaum, J., Currie, S. A., Hartman, R., Kong, Y., Monaghan, R. L., Olson, G., Putter, I., Tunac, J. B., Wallick, H., Stapley, E. O., Oiwa, R. \& Omura, S. (1979). Avermectins, a new family of potent anthelminthic agents: producing organism and fermentation. Antimicrob Agents Chemother 15, 361-367.

Chen, C. W., Yu, T.-W., Lin, Y.-S., Kieser, H. M. \& Hopwood, D. A. (1993). The conjugative plasmid SLP2 of Streptomyces lividans is a $505 \mathrm{~kb}$ linear molecule. Mol Microbiol 7, 925-932.

Dyson, P. \& Schrempf, H. (1987). Genetic instability and DNA amplification in Streptomyces lividans 66. J Bacteriol 169, 4796-4803.

Dyson, P., Betzler, M., Kumar, T. \& Schrempf, H. (1986). Biochemical and genetic analysis of spontaneous genetic instability and DNA amplification in Streptomyces lividans. In Genetics of Industrial Microorganisms. Proceedings of the Fifth International Symposium, Part B, pp. 57-65. Edited by M. Alacevic, D. Hranueli \& Z. Toman. Zagreb: Pliva.

Evans, M. \& Dyson, P. (1993). Pulsed-field gel electrophoresis of Streptomyces lividans DNA. Trends Genet 9, 72.

Hopwood, D. A., Kieser, T., Wright, H. M. \& Bibb, M. J. (1983). Plasmids, recombination, and chromosome mapping in Streptomyces lividans 66. J Gen Microbiol 129, 2257-2269.

Hopwood, D. A., Bibb, M. J., Chater, K. F., Kieser, T., Bruton, C. J., Kieser, H. M., Lydiate, D. J., Smith, C. M., Ward, J. M. \& Schrempf, H. (1985). Genetic Manipulation of Streptomyces: a Laboratory Manual. Norwich: The John Innes Foundation.

Ikeda, H., Kotaki, H. \& Omura, S. (1987). Genetic studies of avermectin biosynthesis in Streptomyces avermitilis. J Bacteriol 169, 5615-5621.
Kieser, T., Hopwood, D. A., Wright, H. M. \& Thompson, C. J. (1982). pI J101, a multi-copy broad host-range Streptomyces plasmid: functional analysis and development of DNA cloning vectors. $\mathrm{Mol}$ \& Gen Genet 185, 223-238.

Kieser, H. M., Kieser, T. \& Hopwood, D. A. (1992). A combined genetic and physical map of the Streptomyces coelicolor A3(2) chromosome. J Bacteriol 174, 5496-5507.

Kinashi, H. (1989). Giant linear plasmids in various methylenomycin-producing strains of Streptomyces species. In Genetics and Molecular Biology of Industrial Microorganisms, pp. 141-146. Edited by C. L. Hershberger, S. W. Queener \& G. Hegeman. Washington, DC: American Society for Microbiology.

Kinashi, H. \& Shimaji-Murayama, M. (1991). Physical characterization of SCP1, a giant linear plasmid from Streptomyces coelicolor. $J$ Bacteriol 173, 1523-1529.

Kinashi, H., Shimaji, M. \& Sakai, A. (1987). Giant linear plasmids in Streptomyces which code for antibiotic biosynthesis genes. Nature 328, 454-456.

MacNeil, D. J. (1988). Characterization of a unique methyl-specific restriction system in Streptomyces avermitilis. J Bacteriol 170, $5607-5612$.

MacNeil, D. J. \& Klapko, L. M. (1987). Transformation of Streptomyces avermitilis by plasmid DNA. J Ind Microbiol 2, 209-218.

Matthew, M. K., Hui, C.-F., Smith, C. L. \& Cantor, C. R. (1988). High resolution separation and accurate size determination in pulsed field gel electrophoresis of DNA. IV. The influence of DNA topology. Biochemistry 27, 9222-9226.

Nasmyth, K. A. (1982). The regulation of yeast mating-type chromatin structure by SIR: an action at a distance affecting both transcription and transposition. Cell 30, 567-578.

Ray, T., Weaden, J. \& Dyson, P. (1992). Tris-dependent site-specific cleavage of Streptomyces lividans DNA. FEMS Microbiol Lett 96, 247-252.

Sambrook, J., Fritsch, E. F. \& Maniatis, T. (1989). Molecular Cloning: a Laboratory Manual, 2nd edn. Cold Spring Harbor, NY: Cold Spring Harbor Laboratory.

Stein, D. S., Kendall, K. J. \& Cohen, S. N. (1989). Identification and analysis of transcriptional regulatory signals for the kil and kor loci of Streptomyces plasmid pIJ101. J Bacteriol 171, 5768-5775.

Tibbetts, M. W., Hafner, E. W., Morgenstein, M. R., Skinner, D. D. \& Denoya, C. D. (1992). Cloning of a DNA fragment involved in pigment production in Streptomyces avermitilis. FEMS Microbiol Lett 91, 9-14.

Vivian, A. (1971). Genetic control of fertility in Streptomyces coelicolor A3(2): plasmid involvement in the interconversion of UF and IF strains. J Gen Microbiol 69, 353-364.

Zhou, X., Deng, Z., Firmin, J. L., Hopwood, D. A. \& Kieser, T. (1988). Site-specific degradation of Streptomyces lividans DNA during electrophoresis in buffers contaminated with ferrous iron. Nucleic Acids Res 16, 4341-4352.

Received 18 November 1993; revised 2 January 1994; accepted 17 January 1994. 